\title{
Folate Receptor-Targeted Tubulysin Conjugate EC1456
}

National Cancer Institute

\section{Source}

National Cancer Institute. Folate Receptor-Targeted Tubulysin Conjugate EC1456. NCI

Thesaurus. Code C113176.

An injectable targeted small molecule drug conjug ate (SMDC) consisting of folate (vitamin B9) covalently linked to the potent mitotic poison and cytotoxic agent, tubulysin B hydrazide (T ub-B-H) with potential antineoplastic activity. Upon administration, the folate moiety of folate receptor-targeted tubulysin conjug ate EC1456 preferentially binds to tumor cells expressing folate receptors (FR). After binding to FR, the agent is internalized by tumor cells and the Tub-B-H moiety inhibits the polymerization of tubulin into microtubules. This may lead to both cell cycle arrest and tumor cell apoptosis. FR, the membrane-bound, high-affinity receptor for folate, is overexpressed on a wide range of primary and metastatic human cancers. 